\title{
The Teacher's Necessity for a Diagnostic Test to Detect Student Weaknesses in Learning Physics in Offline and Online Classes During the COVID-19 Pandemic
}

\author{
Erlita Agustina ${ }^{1, *}$ Supahar $^{2}$ \\ ${ }^{1}$ Master of Physics Education, Faculty of Mathematics and Natural Sciences, Universitas Negeri Yogyakarta, \\ Indonesia \\ ${ }^{2}$ Department of Physics Education, Faculty of Mathematics and Natural Sciences, Universitas Negeri \\ Yogyakarta, Indonesia \\ *Corresponding author. Email: erlitaagustina23@gmail.com
}

\begin{abstract}
This research aims to reveal the teacher's necessity for a diagnostic test to detect the weaknesses of high school students in learning physics. The method used in this research is a survey method. The instrument used is a questionnaire aimed at teachers. 14 physics teachers from several regions in Indonesia became respondents in this research. The questionnaire was analyzed by percentage. The survey questionnaire contains aspects of enthusiasm in learning physics, the results of learning physics in class (offline), the results of learning physics online during the COVID-19 pandemic, and the necessity for diagnostic tests. The results of this research indicate that $92.9 \%$ of respondents require a diagnostic test to detect student weaknesses in learning physics. The existence of a physics diagnostic test can help the work of teachers in detecting student weaknesses. Diagnostic tests are not only needed during offline learning in class but also during online learning because students often experience difficulties in learning physics offline and online.
\end{abstract}

Keywords: Diagnostic test, Physics

\section{INTRODUCTION}

In early 2020 the world began to be shocked by the spread of the coronavirus. New cases of the coronavirus (COVID-19) that have emerged in the Wuhan area, China have spread rapidly throughout the world [1]. The rapid rate of spread directly has a negative impact on every sector of human life [2]. The education sector has not escaped the attacks of the COVID-19 pandemic. No one has prepared the handling of the education crisis caused by COVID19. The whole world is closing schools. This has an unknown impact on millions of students around the world. 'Emergency distance teaching' was adopted as a temporary solution to reduce the effects of the COVID-19 pandemic on education [3]. COVID-19 has hit most areas of the world and is starting to affect students' normal school life. Each country is looking for ways to minimize the impact of the pandemic on the education sector. Online learning is a step taken by many countries. From elementary schools to college, from Europe, Asia, to North America has become large-scale online learning places. The 'School is Out, but Class is On' online teaching system has been launched throughout China. The Chinese government implements a "School is Out, but Class is On" system by combining all teaching, internet and IT resources to support distance learning during the COVID-19 pandemic. As a new learning method, online teaching is also supported by national, local information companies, platform providers, or various resources that help smoothness learning [4]. The implementation of the "School is Out, but Class is On" system is supported by online education. The problem in learning is how to use the network for learning, manage to learn, and maintain the health of teachers and students in order to create efficient and quality online learning [5]. The closure of all educational institutions and 
recommended self-isolation programs for residents in an effort to control the spread of COVID-19. This has a negative impact on student learning in 2020 [2]. Physics is still one of the students' subjects in 2020.

Physics is a subject commonly encountered by high school students. Physics is still one of the most difficult subjects for students. There is a lot of physics material, abstract, complex, and there is mathematics which is quite complicated to make students difficult. This causes students' interest in learning to be low and affects physics learning outcomes [6]. Various kinds of different things become the basis of student difficulties in learning physics. Physics is difficult to learn, physics concepts are abstract, systems in physics tend to be complicated, students' previous knowledge is limited, and students can have misunderstandings. The absence of theoretical associations with life, difficulties in understanding and perceiving physics concepts, many concepts that must be memorized, less creative classical approaches, and lack of understanding in solving physics problems are the reasons for the decline in physics knowledge [7]. Most students have difficulty understanding the concepts in physics learning [8]. Many physics formulas make it difficult for students to learn, apply them, and make students confused about choosing formulas that can be used to solve physics problems. When students learn existing examples, students can understand them well. However, when students find new questions, students have trouble solving it correctly. This problem encourages efforts to find solutions to these problems [6]. Students are still wrong in solving problems because students have difficulty using their knowledge. Although students have conducted experiments and discussed it with the teacher. The mistakes made by students do not mean students do not have the knowledge, but students cannot use this knowledge [9]. Information about the difficulties students have is a very important component to be able to achieve effective physics teaching [10]. The weakness of students in understanding the lesson can hinder the process of absorbing new knowledge after learning [8]. Therefore, the weaknesses that students have must be detected immediately

Student weaknesses need to be assessed in order to create effective learning. The teacher also needs accurate information about student weaknesses [11]. Assessment is one way that can help detect student weaknesses. Assessment is a common activity in schools. This also helps the process of developing student learning. The assessment helps teachers to assess the teaching that has been done to improve student learning [12]. To be able to detect student weaknesses, an instrument that can reveal it is needed [13]. Diagnosing student weaknesses in a valid and reliable way is very important in science learning. Diagnostic tests can be an assessment tool related to students' recurring learning difficulties and the causes of their learning difficulties. Diagnostic test instruments can distinguish what teachers want students to know and what students actually know [14]. Then the diagnostic test can be used to detect student weaknesses in learning physics.

Various kinds of diagnostic tests have been developed. Physical diagnostic tests with the subject of simple harmonic motion [8],[10],[15], state of matter [16], Newton's law [17], the elasticity of solid materials [18], static electricity [13], energy and the concept of momentum [19]. Diagnostic tests to detect misconceptions [8],[13],[19], error patterns [11], creative thinking [18]. Diagnostic test with multiplechoice format and open reasons [9],[15], survey [10], three-tier multiple-choice test [16], four-tier multiplechoice test [8],[13],[19]. Diagnostic tests that have been developed by researchers give confidence that diagnostic tests can be developed for a variety of student weaknesses, subject matter, and various formats.

The various diagnostic test formats have their own characteristics. Interviews are advantageous in the detailed investigation and cognitive abilities of students. However, an unfair or biased interviewer can lead to an error in the results of the interview. Open tests give students enough time to think about and write their own answers, observe the mistakes that students have, find out the reasons for student confusion. However, this test has a weakness where not all students know their weaknesses, have time, and are willing to write down their own weaknesses [14],[17]. Regular multiple-choice tests have the advantage of being valid and reliable, easy to achieve, and easy to administer. This test requires the teacher's ability to understand student answers. The use of regular multiple-choice tests allows the occurrence of "true negative" and "false positive" for reasons that are stored in students. The two-tier test consists of the first level which contains multiplechoice problems and the second level contains the reasons for the answer in the first level [17]. Two-tier tests are usually better than conventional multiplechoice tests. The reason conventional multiple-choice tests are not so good is that they can raise the possibility of "false positive" and "false negative" answers. "False positive" is defined as the correct answer but wrong in reasoning. Meanwhile, the answer "false negative" means the answer is wrong 
but the reasoning is right. This must be minimized so that the test is more valid. Although the two-tier test is used to improve the conventional multiple-choice test, it has limitations. The two-stage test cannot detect a lack of knowledge [16]. The three-tier test aims to perfect the two-tier test [13]. The three-tier test has an important role in determining whether the answers to the previous two levels are due to misunderstanding or lack knowledge [17]. Three-tier diagnostic test. The first level is in the form of regular multiple-choice tests, the second level asks for reasons, and the third level asks the level of student confidence in the answers at the first and second levels [20]. The three-tier test can detect knowledge deficiencies. The three-tier test has a weakness in differentiating students' beliefs in the first or second level [17]. The four-tier test complements the three-tier test [13]. The four-tier test consists of the first level which contains a conventional multiple-choice test. The second level contains questions about students' beliefs about students' confidence in the answers given at the first level. The third level contains the reasons for the response at the first level. The fourth level contains students' confidence in the choice of reasons given at the second level [17]. The pros and cons of each diagnostic test format have been well researched by researchers. The advantages and disadvantages of each diagnostic test format have been well researched by the researchers.
Research on diagnostic tests has been done quite a lot in the country or abroad. The research shows the need for a diagnostic test to detect student weaknesses. This student weakness occurs during normal times with learning at school or during the COVID-19 pandemic where learning is carried out online. But what about the teacher's own opinion? Do teachers think that a diagnostic test is needed to detect student weaknesses in learning physics? So this study aims to reveal the teacher's necessity for a diagnostic test to detect the weaknesses of high school students in learning physics.

\section{RESEARCH METHOD}

This type of research is survey research. The research was conducted in September 2020. The sample consisted of 14 physics teachers in several places in Indonesia such as Banten, Riau, Solo, Yogyakarta, and others. The data analysis technique used quantitative descriptive analysis from the questionnaire results. The questionnaire contains several aspects studied enthusiasm in learning physics, the results of learning physics in class (offline), the results of learning physics online during the COVID-19 pandemic, knowledge of diagnostic tests, and the necessity for diagnostic tests based on the opinion of the teacher. Table 1 shows the blueprint of the questionnaire made.

Table 1. Blueprint table of teacher needs for diagnostic tests

\begin{tabular}{|c|c|c|c|}
\hline No & Aspect & Indicator & $\begin{array}{l}\text { Number } \\
\text { Questionnaire }\end{array}$ \\
\hline 1 & Enthusiasm in learning physics & $\begin{array}{l}\text { The teacher's opinion on the enthusiasm of } \\
\text { students during physics lessons }\end{array}$ & 1 \\
\hline \multirow[t]{4}{*}{2} & \multirow[t]{4}{*}{$\begin{array}{l}\text { Results of learning physics in } \\
\text { class (offline) }\end{array}$} & $\begin{array}{l}\text { The teacher's opinion on student difficulties } \\
\text { in physics lessons }\end{array}$ & 2 \\
\hline & & Student physics test scores & 4 \\
\hline & & $\begin{array}{l}\text { Teacher's knowledge of the causes of } \\
\text { student weaknesses in learning physics }\end{array}$ & 6 \\
\hline & & $\begin{array}{l}\text { Experience of teachers using diagnostic } \\
\text { tests }\end{array}$ & 9 \\
\hline \multirow[t]{4}{*}{3} & \multirow[t]{4}{*}{$\begin{array}{l}\text { Results of online physics learning } \\
\text { during the COVID-19 pandemic }\end{array}$} & $\begin{array}{l}\text { The teacher's opinion on student difficulties } \\
\text { in physics lessons }\end{array}$ & 3 \\
\hline & & Student physics test scores & 5 \\
\hline & & $\begin{array}{l}\text { Teacher's knowledge of the causes of } \\
\text { student weaknesses in learning physics }\end{array}$ & 7 \\
\hline & & Experience of teachers using diagnostic & 10 \\
\hline
\end{tabular}




\begin{tabular}{|c|c|c|c|}
\hline No & Aspect & Indicator & $\begin{array}{l}\text { Number } \\
\text { Questionnaire }\end{array}$ \\
\hline & & tests & \\
\hline \multirow[t]{4}{*}{4} & \multirow[t]{4}{*}{ The necessity for diagnostic tests } & Teacher knowledge about diagnostic tests & 8 \\
\hline & & Teacher necessity for diagnostic tests & 11 \\
\hline & & $\begin{array}{l}\text { The necessity for diagnostic tests for each } \\
\text { chapter }\end{array}$ & 12 \\
\hline & & $\begin{array}{l}\text { Teacher opinion about diagnostic tests to } \\
\text { facilitate teacher performance }\end{array}$ & 13 \\
\hline
\end{tabular}

\section{RESULT AND DISCUSSION}

The data of this research were obtained from the percentage of teacher opinions which were then analyzed to determine the teacher's necessity for diagnostic tests in physics learning. The results of the questionnaire were divided into several aspects. The discussion of the questionnaire results from each of the following aspects was as follows.

Learning in schools always involves the presence of teachers and students. Over time, teachers can instinctively see the enthusiasm of students in participating in physics lessons. The survey results proved that $64.3 \%$ of the teachers thought that as long as the teacher taught the students were enthusiastic in following physics lessons given by the teacher. These results are shown in Table 2 about the aspects of enthusiasm in physics lessons.

Table 2. Teachers 'opinions about students' enthusiasm during physics lessons

\begin{tabular}{|l|l|l|l|}
\hline \multirow{2}{*}{ No } & Question & \multicolumn{2}{|c|}{ Results (\%) } \\
\cline { 3 - 4 } & Yes & No \\
\hline 1 & $\begin{array}{l}\text { Based on the teaching } \\
\text { experience of the teachers, } \\
\text { are students enthusiastic } \\
\text { about taking physics lessons? }\end{array}$ & 64,3 & 35,7 \\
\hline
\end{tabular}

Physics learning is usually done face-to-face directly between the teacher and students in the class or it can be called offline learning. Data on learning in class (offline) are shown in Table 3. Based on the teacher's experience during class teaching, students have difficulty understanding physics lessons are given by the teacher. This is in accordance with the results of previous research that students still have difficulty learning physics [7], [8], [10]. Students also do not always get satisfactory scores when given a physics test. Most teachers know the weaknesses of students that make it difficult for students to get satisfactory scores on physics tests. But $64.3 \%$ of the respondents have never used a physics diagnostic test when learning in class. However, the way teachers find out the weaknesses of students has not used a diagnostic test.

Table 3. Teachers' opinions about the results of learning physics in class (offline)

\begin{tabular}{|l|l|l|l|}
\hline \multirow{2}{*}{ No } & Question & \multicolumn{2}{|l|}{ Results (\%) } \\
\cline { 3 - 4 } & & Yes & No \\
\hline 1 & $\begin{array}{l}\text { In your opinion, are there } \\
\text { students who have difficulty } \\
\text { understanding physics lessons } \\
\text { when studying in class } \\
\text { (offline)? }\end{array}$ & 85,7 & 14,3 \\
\hline 2 & $\begin{array}{l}\text { Do all the students taught by } \\
\text { the teacher always get } \\
\text { satisfactory scores from the } \\
\text { physics material test results } \\
\text { given during class (offline)? }\end{array}$ & 21,4 & 78,6 \\
\hline 3 & $\begin{array}{l}\text { Do you know the weaknesses } \\
\text { of students that make it } \\
\text { difficult for students to get } \\
\text { satisfactory grades when } \\
\text { learning physics in class } \\
\text { (offline)? }\end{array}$ & $\begin{array}{l}85,7 \\
\text { student weaknesses in doing } \\
\text { physics questions during class } \\
\text { (offline)? }\end{array}$ & 14,3 \\
\hline Have you ever used a & 35,7 & 64,3 \\
\hline
\end{tabular}


The time of the COVID-19 pandemic in Indonesia requires students to study online from their homes. Apart from Indonesia, other countries such as Portugal and China have also implemented online learning during the COVID-19 pandemic [3]-[5]. Changes in the learning system that was previously offline must be turned online to have an impact on learning physics. In fact, $100 \%$ of the teachers who were respondents in this study stated that students had difficulty understanding physics lessons when learning online. The percentage of students who did not score well on the physics test during online learning was greater than when learning physics offline before the COVID-19 pandemic. This is in accordance with the opinion that the spread of COVID-19 has an impact on the education sector [2], [3]. Just like when learning offline, when learning online the teacher knows the causes of student difficulty in getting good grades on physics tests. However, $85.7 \%$ of respondents have not used a diagnostic test when learning online. The results of online physics learning during the COVID-19 pandemic can be seen in Table 4 .

Table 4. Teachers' opinions about the results of online physics learning during the COVID-19 pandemic

\begin{tabular}{|l|l|l|l|}
\hline \multirow{2}{*}{ No } & Question & \multicolumn{2}{|l|}{ Results (\%) } \\
\cline { 3 - 4 } & & Yes & No \\
\hline 1 & $\begin{array}{l}\text { In your opinion, are there any } \\
\text { students who have difficulty } \\
\text { understanding physics lessons } \\
\text { while studying online during the } \\
\text { CoviD-19 pandemic? }\end{array}$ & 100 & 0 \\
\hline 2 & $\begin{array}{l}\text { Do all students taught by the } \\
\text { teacher always get satisfactory } \\
\text { scores from the physics material } \\
\text { test results given during online } \\
\text { learning during the COVID-19 } \\
\text { pandemic? }\end{array}$ & 14,3 & 85,7 \\
\hline 3 & $\begin{array}{l}\text { Do you know the weaknesses of } \\
\text { students that made it difficult } \\
\text { for students to get satisfactory } \\
\text { scores when learning physics } \\
\text { online during the COVID-19 } \\
\text { pandemic? }\end{array}$ & $\begin{array}{l}78,6 \\
\text { Have you ever used a } \\
\text { diagnostic test to detect student }\end{array}$ & 21,4 \\
\hline 4
\end{tabular}

\begin{tabular}{|l|l|l|l|}
\hline \multirow{2}{*}{ No } & Question & \multicolumn{2}{|c|}{ Results (\%) } \\
\cline { 3 - 4 } & $\begin{array}{l}\text { Yes } \\
\text { weaknesses in solving physics } \\
\text { questions during online learning } \\
\text { during the COVID-19 } \\
\text { pandemic? }\end{array}$ & & \\
\hline
\end{tabular}

Research results showed that some teachers who were respondents had never used a diagnostic test when learning offline or online. In fact, $92.9 \%$ of teachers require a diagnostic test in physics learning. The teacher also hopes that it would be better if the diagnostic test itself can be made for each physics subject matter. $100 \%$ of the teachers who became respondents agreed that the diagnostic test could help teacher performance in detecting student weaknesses in physics lessons. The research that has been conducted shows that the need for teachers for physics diagnostic tests is relatively high. The opinion of the teacher's need for diagnostic tests in physics can be seen in Table 5 .

Table 5. Teachers' opinions on the need for diagnostic tests

\begin{tabular}{|l|l|l|l|}
\hline \multirow{2}{*}{ No } & Question & \multicolumn{2}{|l|}{ Results (\%) } \\
\cline { 3 - 4 } & & Yes & No \\
\hline 1 & $\begin{array}{l}\text { In your opinion, do teachers } \\
\text { need a diagnostic test to detect } \\
\text { student weaknesses in learning } \\
\text { physics? }\end{array}$ & 92,9 & 7,1 \\
\hline 2 & $\begin{array}{l}\text { In your opinion, does a } \\
\text { diagnostic test teacher need to } \\
\text { be made for each chapter on } \\
\text { physics subject matter? }\end{array}$ & 85,7 & 14,3 \\
\hline 3 & $\begin{array}{l}\text { Do you agree that diagnostic } \\
\text { tests can make it easier for } \\
\text { teachers to detect student } \\
\text { weaknesses in physics lessons? }\end{array}$ & 100 & 0 \\
\hline
\end{tabular}

The results of the questionnaire given to the teacher showed that based on the teacher's experience during teaching, students were enthusiastic about participating in physics learning. However, students still have difficulty understanding physics lessons given by teachers both offline in class and online during the COVID-19 pandemic. Students also have difficulty getting satisfactory physics test scores. The COVID-19 pandemic that hit Indonesia requires students to study online. Researchers saw the results 
of the teacher's opinion on online learning, making the percentage of students who had difficulty getting good grades greater than when learning offline. In general, teachers know the weaknesses that cause students to have difficulty getting good physics scores but the teacher has not used diagnostic tests to detect actual student weaknesses. Most teachers think that a test is needed to detect student weaknesses, namely a diagnostic test. This diagnostic test can be made for each chapter of physics subject matter. $100 \%$ of teachers believe that diagnostic tests can facilitate teacher performance in detecting student weaknesses in physics lessons

\section{CONCLUSION}

The results of the research that have been conducted show that teachers need a diagnostic test to detect student weaknesses in learning physics. The existence of a physics diagnostic test can help the work of teachers in detecting student weaknesses. Diagnostic tests are not only needed during offline learning in class but also during online learning because students often experience difficulties in learning physics offline and online

\section{REFERENCES}

[1] N.C. Wickramasinghe, E.J. Steele, R.M. Gorczynski, et al., Growing Evidence Against Global Infection-Driven by Person-to-Person Transfer of COVID-19, Virology: Current Research 4(1) (2020) 18-21. DOI: https://doi.org/10.37421/virolcurrres.2020.4.110

[2] E.J. Sintema, Effect of COVID-19 on The Performance of Grade 12 Students: Implications for STEM Education, Eurasia Journal of Mathematics, Science and Technology Education 16(7) (2020) 1-6. DOI: https://doi.org/10.29333/ejmste/7893

[3] M. Assunção Flores, M. Gago, Teacher Education in Times of COVID-19 Pandemic in Portugal: National, Institutional and Pedagogical Responses, Journal of Education for Teaching 46(4) (2020) 507-516. DOI: https://doi.org/10.1080/02607476.2020.1799709

[4] L. Zhou, F. Li, A Review of the Largest Online Teaching in China for Elementary and Middle School Students during The COVID-19 Pandemic, Best Evidence of Chinese Education 5(1) (2020) 549-567. DOI: https://doi.org/10.15354/bece.20.re040
[5] D. Dai, G. Lin, Online Home Study Plan for Postponed 2020 Spring Semester during the COVID-19 Epidemic: A Case Study of Tangquan Middle School in Nanjing, Jiangsu Province, China, SSRN Electronic Journal 4(2) (2020) 543-547. DOI: https://doi.org/10.2139/ssrn.3555539

[6] A. Koswara, M. Mundilarto. Pengembangan Handout Fluida Dinamik Terintegrasi Metakognisi untuk Meningkatkan Kemampuan Aplikasi Siswa Developing Handout of Fluid Dynamics Integrated by Metacognition to Improve Application Ability of Students, Jurnal Inovasi Pendidikan IPA 4(1) (2018) 11-25. DOI: https://doi.org/10.21831/jipi.v4i1.6193

[7] F.H. Alanazi, The Effectiveness of The 4MAT Teaching Approach in Enhancing Conceptions of Electricity in Physics for Female Students in the Kingdom of Saudi Arabia, Journal of Turkish Science Education 17(2) (2020) 271288.

DOI:

https://doi.org/10.36681/tused.2020.26

[8] A.M.R. Tumanggor, S. Supahar, E.S. Ringo, M.D. Harliadi, Detecting Students' Misconception in Simple Harmonic Motion Concepts Using Four-Tier Diagnostic Test Instruments, Jurnal Ilmiah Pendidikan Fisika AlBiruni 9(1) (2020) 21-31. DOI: https://doi.org/10.24042/jipfalbiruni.v9i1.4571

[9] Y.D. Sugara, S. Sutopo, E. Latifah, Pemikiran Siswa Ketika Menyelesaikan Soal-Soal Textbook dan Real-World, Jurnal Pendidikan: Teori, Penelitian, dan Pengembangan 2(11) (2017) 1534-1538. DOI: https://doi.org/10.17977/jptpp.v2i11.10227

[10] S. Somroob, P. Wattanakasiwich, Investigating student understanding of simple harmonic motion, in: Siam Physics Congress (Rayong), vol. 901, IOP Publishing, Bristol, 2017, pp. 1-4. DOI: https://doi.org/10.1088/17426596/901/1/012123

[11] S. Kusairi, A. Hidayat, N. Hidayat, Web-Based Diagnostic Test: Introducing Isomorphic Items to Assess Students' Misconceptions and Error Patterns, Chemistry: Bulgarian Journal of Science Education 26(4) (2017) 526-539.

[12] M. Ramadani, S. Supahar, D. Rosana, Validity of Evaluation Instrument on The Implementation of Performance Assessment to Measure Science Process Skills, Jurnal Inovasi 
Pendidikan IPA 3(2) (2017) 180-188. DOI: https://doi.org/10.21831/jipi.v3i2.15534

[13] N. Hermita, A. Suhandi, E. Syaodih, et al., Constructing and implementing a four tier test about static electricity to diagnose pre-service elementary school teacher' misconceptions, in: International Conference on Mathematics and Science Education, vol. 895, IOP Publishing, Bristol, 2017, pp. 1-6. DOI: https://doi.org/10.1088/1742-6596/895/1/012167

[14] D.K. Gurel, A. Eryilmaz, L.C. McDermott, A Review and Comparison of Diagnostic Instruments to Identify Students' Misconceptions in Science, EURASIA Journal of Mathematics, Science and Technology Education 11(5) (2015) 989-1008. DOI: https://doi.org/10.12973/eurasia.2015.1369a

[15] D.A. Nugraha, C. Cari, A. Suparmi, W. Sunarno, Physics students' answer on simple harmonic motion, in: 9th International Conference on Physics and Its Applications, vol. 1153, IOP Publishing, Bristol, 2019, 1-6. DOI: https://doi.org/10.1088/17426596/1153/1/01215 1

[16] Z.D. Kirbulut, O. Geban, Using Three-Tier Diagnostic Test to Assess Students' Misconceptions of States of Matter, EURASIA Journal of Mathematics, Science and Technology Education 10(5) (2014) 509-521. DOI:

https://doi.org/10.12973/eurasia.2014.1128a

[17] I. Kaniawati, N.J. Fratiwi, A. Danawan, I. Suyana, A. Samsudin, E. Suhendi, Analyzing students' misconceptions about Newton's Laws through Four-Tier Newtonian Test (FTNT), Journal of Turkish Science Education 16(1) (2019) 110-122. DOI: https://doi.org/10.12973/tused.10269a

[18] J.R. Batlolona, M. Diantoro, Wartono, E. Latifah, Creative Thinking Skills Students in Physics on Solid Material Elasticity, Journal of Turkish Science Education 16(1) (2019) 48-61. DOI: https://doi.org/10.12973/tused.10265a

[19] N.F. Afif, M.G. Nugraha, A. Samsudin. Developing energy and momentum conceptual survey (EMCS) with four-tier diagnostic test items, in: Mathematics, Science, and Computer Science Education, vol. 1848, American Institute of Physics, Maryland, 2017, pp. 1-5. DOI: https://doi.org/10.1063/1.4983966
[20] F.D. Mubarokah, S. Mulyani, N.Y. Indriyanti, Identifying Students' Misconceptions of AcidBase Concepts Using A Three-Tier Diagnostic Test: A Case of Indonesia and Thailand, Journal of Turkish Science Education 15 (Special Issue) (2018) 51-58. DOI: https://doi.org/10.12973/tused.10256a 